\title{
ANALISIS KADAR HARA PUPUK ORGANIK KASCING DARI LIMBAH KANGKUNG DAN BAYAM
}

\author{
Elfayetti ${ }^{1}$, Mahara Sintong1, Kamarlin Pinem ${ }^{1}$, L. Primawati ${ }^{2}$ \\ 1Dosen Jurusan Pendidikan Geografi Fakultas Ilmu Sosial, Universitas Negeri Medan \\ Jl. Willem Iskandar Psr V Medan Estate Medan, 20211 Indonesia \\ 2Dosen Universitas HKBP Nommensen \\ Jl. Perintis Kemerdekaan No.23 Medan, 20218 Indonesia \\ Email: elfayetti@yahoo.com
}

\begin{abstract}
Abstrak
Pertanian organik merupakan sistem pertanian yang holistik yang mendukung dan mempercepat biodeversiti, siklus biologi dan aktivitas biologi tanah(International Federation of Organic Agriculture Movements,2014). Geografi Pertanian merupakan mata kuliah di Jurusan Pendidikan Geografi FIS Unimed. Dalam Kurikulum Berbasis Kompetensi yang diterapkan di Jurusan Pendidikan Geografi FIS Unimed merupakan matakuliah wajib pada semester genap, tepatnya pada semester IV (empat). Penelitian ini bertujuan untuk mengetahui kemampuan pertumbuhan berat cacing tanah pada pupuk kascing dari limbah kangkung dan bayam dan untuk mengetahui kandungan hara $N, P$, $K$ dan $\mathrm{pH}$ kascing dari limbah kangkung dan bayam pada tanah ultisol. Untuk mengatasi permasalahan pada pupuk organik, maka harus diupayakan bagaimana memperoleh pupuk yang memiliki unsur hara yang padat dan pengadaannya relatif murah dan mudah. Pemanfaatan limbah organik untuk budidaya cacing tanah merupakan salah satu tindakan yang tepat untuk mencapai tujuan tersebut. Rendahnya bahan organik, $N, P, K$ menunjukkan bahwa tanah pada percobaan ini membutuhkan bahan organik. Pemberian bahan organik seperti cacing diharapkan dapat meningkatkan Produktivitas Ultisol dimana Kascing mempunyai sifat-sifat kimia, fisika, dan biologi tanah yang baik, sehingga dapat meningkatkan serapan hara dan pertumbuhan tanaman. Berdasarkan hasil penelitian maka dapat disimpulkan bahwa: 1. Jenis makanan berpengaruh terhadap pertumbuhan cacing tanah dan kualitas kascing yang dihasilkan. 2.Terdapat perbedaaan pada bobot cacing tanah yang dihasilkan dengan adanya perbedaan jenis makanan. Jenis makanan bayam memberikan tingkat pertumbuhan cacing tanah terbaik dengan terjadinya pertambahan bobot sebesar 650 gram yang awalnya hanya 250 gram. 3. Dari beberapa parameter sifat kimia dan biologi kascing, maka jenis makanan bayam memberikan nilai $N$ tertinggi yaitu 0,52 dan pada pakan kangkung terdapatnilai $p$ tertinggi yaitu 0,35 .
\end{abstract}

Kata Kunci : pertanian, oganik, pupuk, kascing

\section{PENDAHULUAN}

Pertanian organik

merupakan sistem pertanian yang holistik yang mendukung dan mempercepat biodeversiti, siklus biologi dan aktivitas biologi tanah.(International Federation of Organic Agriculture Movements,2014). Pertanian organik mendasarkan pada 4 prinsip sebagai berikut : (a ) Prinsip Kesehatan (b) Prinsip Ekologi (c) Prinsip Keadilan (d) Prinsip Perlindungan. Setiap prinsip dinyatakan melalui suatu pernyataan disertai dengan penjelasannya. Prinsip-prinsip ini harus digunakan secara menyeluruh dan dibuat sebagai prinsip-prinsip etis yang mengilhami tindakan dalam penerapan sistem pertanian organik.

a. Prinsip Kesehatan. Pertanian organik harus melestarikan dan meningkatkan kesehatan tanah, tanaman, hewan, manusia dan bumi 
sebagai satu kesatuan yang tak terpisahkan. Prinsip ini menunjukkan bahwa kesehatan tiap individu dan komunitas tidak dapat dipisahkan dari kesehatan ekosistem secara keseluruhan. Secara khusus, pertanian organik dimaksudkan untuk menghasilkan produksi pangan bermutu tinggi dan bergizi untuk mendukung pemeliharaan kesehatan dan kesejahteraan masyarakat. Mengingat hal tersebut, maka harus dihindari penggunaan pupuk sintetik, pestisida, obat-obatan kimia pada hewan, bahan aditif makanan yang dapat berefek merugikan pada kesehatan.

b. Prinsip Ekologi. Prinsip ini mendasarkan pada sistem dan siklus ekologi kehidupan. Pertanian organik dapat mencapai keseimbangan ekologis melalui pola sistem pertanian alamiah, membangun habitat, pemeliharaan keragaman genetika dalam pertanian. Mereka yang menghasilkan, memproses, memasarkan dan mengonsumsi produk-produk pertanian organik harus melindungi dan memberikan keuntungan bagi lingkungan secara umum termasuk di dalamnya tanah, iklim, habitat, keragaman hayati, udara dan air.

c. Prinsip Keadilan. Pertanian Organik harus membangun hubungan yang mampu menjamin keadilan terkait dengan lingkungan dan kesempatan hidup bersama. Pertanian organik harus memberikan kualitas hidup yang baik bagi setiap orang yang terlibat, menyumbang bagi kedaulatan pangan dan pengurangan kemiskinan. Pertanian organik bertujuan untuk menghasilkan kecukupan dan ketersediaan pangan dengan kualitas yang baik.

d. Prinsip Perlindungan. Pertanian Organik harus dikelola secara hatihati dan bertanggung jawab untuk melindungi kesehatan dan kesejahteraan generasi sekarang dan generasi mendatang serta lingkungan hidup. Pertanian organik harus mampu mencegah terjadinya resiko merugikan dengan menerapkan teknologi tepat guna dan menolak teknologi yang tak dapat diramalkan akibatnya, seperti misalnya rekayasa genetika (genetic engineering). Segala keputusan harus mempertimbangkan nilai-nilai dan kebutuhan dari semua aspek yang mungkin dapat terkena dampaknya, melalui proses-proses yang transparan dan partisipatif.

Keempat prinsip di atas merupakan dasar bagi pertumbuhan dan perkembangan pertanian organik dan merupakan sebuah visi untuk meningkatkan keseluruhan aspek secara global.

Pembangunan di bidang pertanian dewasa ini cukup berhasil dilakukan, dampak positif terlihat pada meningkatnya produksi di sektor ini. Namun demikian, disadari atau tidak sikap petani dalam pola bertani banyak mengalami perubahan. Para petani lebih cenderung menggunakan pupuk anorganik dari pada pupuk organik. Banyak faktor yang menjadi alasan mengapa petani bersikap demikian, diantaranya adalah cara pemakaian pupuk anorganik yang lebih praktis dan kandungan haranya yang lebih tinggi. Di samping itu, penggunaan pupuk organik sering mengalami kesulitan karena jumlahnya relatif sedikit dan terbatas serta kualitasnya kurang baik.

Penggunaan pupuk anorganik secara terus menerus tanpa penambahan pupuk organik dapat menurunkan kualitas tanah baik secara fisik, biologi maupun kimia. Menurut kualitas tanah menyebabkan menurunnya kemampuan tanah untuk mendukung pertumbuhan dan produksi tanaman. Penggunaan pupuk anorganik yang berlebihan dapat pula menyebabkan pencamaran dan mengganggu keseimbangan alam serta menambah beban biaya bagi petani. Untuk megatasi 


\section{ge Ografi}

permasalahan di atas perlu dicari pemecahannya.

Dewasa ini petani dan masyarakat sudah menyadari bahwa penggunaan pupuk anorganik banyak menimbulkan masalah terutama terhadap kesehatan, sehingga mereka mulai beralih menggunakan pupuk anorganik ke pupuk organik. Bahkan para pengusaha yang bergerak di bidang agrobisnis sedang giatgiatnya menggunakan pupuk organik untuk berbagai jenis tanaman, sehingga kita mengenal adanya sayur-sayuran organik dan buah-buahan organik. Bahkan di negara-negara maju penggunaan pupuk organik ini sudah lama dilakukan, karena mereka menyadari bahwa penggunaan pupuk anorganik sangat berbahaya bagi kesehatan.

Di Indonesia, revolusi hijau dikenal dengan istilah swasembada pangan yang memberikan hasil signifikan terhadap pemenuhan kebutuhan pangan ketika itu. Dimana penggunaan pupuk kimia sintesis, penanaman varietas unggul berproduksi tinggi (high yield variety), penggunaan pestisida, intensifikasi lahan dan lainnya mengalami peningkatan.

Namun belakangan ditemukan berbagai permasalahan akibat kesalahan manajemen dalam hal pengolahan lahan pertanian. Pencemaran pupuk kimia, pestisida dan lainnya akibat kelebihan pemakaian bahan-bahan kimia tersebut, kini berdampak terhadap penurunan kualitas lingkungan dan kesehatan manusia akibat selalu tercemar bahanbahan kimia sintesis tersebut.

Untuk mengatasi permasalahan pada pupuk organik, maka harus diupayakan bagaimana memperoleh pupuk yang memiliki unsur hara yang padat dan pengadaannya relatif murah dan mudah. Pemanfaatan limbah organik untuk budidaya cacing tanah merupakan salah satu tindakan yang tepat untuk mencapai tujuan tersebut.

Cacing tanah termasuk salah satu makhluk hidup penghuni tanah yang
Available at http://jurnal.unimed.ac.id/2012/index.php/geo e-ISSN: 2549-7057 | p-ISSN: 2085-8167

secara langsung maupun tidak langsung bayak berperan dalam kehidupan manusia. Diantaranya manfaat cacing tanah dapat menyuburkan tanah, memperbaiki dan mempertahankan struktur tanah dan dari aktivitas metabolismenya dapat menghasilkan pupuk organik yang sering disebut dengan kascing. Menurut Sudirja (1999), kascing merupakan hasil pragmentasi bahan organik oleh aktivitas cacing tanah secara fisik dan kimia yang bercampur dengan kotoran yang dikeluarkannya yang kaya sel-sel hidup mikroba.

Bahan organik sebagai sumber makanan bagi cacing tanah bermacamacam. Suim (1998), melaporkan bahwa kualitas dan kuantitas dari makanan tersebut merupakan faktor penting dalam pengontrolan biomassa cacing tanah dan jumlah feses yang dihasilkan. Diduga akan terjadi perbedaan kandungan hara dan banyak kascing yang dihasilkan apabila makanan cacing tanah tersebut berbeda.Kualitas pupuk yang dihasilkan oleh kascing diharapkan dapat memperbaiki kondisi tanah terutama tanah-tanah yang miskin seperti utisol (tanah yang memilki sifat kimia, fisika dan biologi yang kurang menguntungkan).

Pemakaian pupuk organik kascing untuk tanaman disebut juga dengan pertanian organik. Pertanian organik didefenisikan sebagai sistem produksi pertanian yang holistik dan terpadu, dengan cara mengoptimalkan kesehatan dan produktivitas agro-ekosistem secara alamiah, sehingga menghasilkan pangan yang berkualitas, dan berkelanjutan.

Berdasarkan uraian di atas, maka dirumuskan masalah penelitian sebagai berikut:

(1) Bagaimanakah pertumbuhan berat cacing tanah pada pupuk kascing yang dihasilkan dengan jenis limbah kangkung dan bayam?; (2) Bagaimanakah kandungan hara kascing $\mathrm{N}, \mathrm{P}, \mathrm{K}$ dan $\mathrm{pH}$ yang dibuat dari limbah kangkung dan bayam pada tanah ultisol. Hasil penelitian 
ini diharapkan dapat menjadi alternatif dalam pembuatan pupuk organik secara cepat dan kaya dengan unsur hara dengan memanfaatkan cacing tanah, dapat membantu memecahkan masalah pencemaran lingkaran akibat limbah organic, serta dapat memberikan keterampilan bagi mahasiswa dalam pembuatan pupuk organik dari berbagai jenis limbah yang ada.

\section{METODE PENELITIAN}

Penelitian dilaksanakan pada bulan Oktober sampai Desember 2015. Percobaan tahap I dan II dilaksanakan diruang pengeringan tanah Jurusan tanah Fakultas Pertanian Universitas Sumatera Utara. Analisis kascing dan analisis tanah dilaksanakan di laboratorium biologi tanah, laboratorium kimia tanah dan laboratorium Hama dan penyakit tanaman Fakultas Pertanian USU Medan.

Pada penelitian ini digunakan cacing tanah spesies Lumbricus rubeltus, yang bibitnya akan diperoleh dari laboratorium biologi tanah fakultas pertanian USU Medan. Sebagai media hidup cacing tanah digunakan sekam kayu, kotoran sapi dan kotoran ayam. Untuk perlakuan jenis makanan cacing tanah digunakan kol dan ampas tahu. Alat-alat yang digunakan dalam penelitian ini adalah wadah pemeliharaan cacing tanah, rak, timbangan, poly bag ukuran $1 \mathrm{~kg}$ dan alat pengaduk lainnya.

Penelitian ini dilaksanakan dalam

Tabel 2. Penilaian Sifat Kimia Tanah berikut ini :

\begin{tabular}{|c|c|c|c|}
\hline Sifat Tanah & Rendah & Sedang & Tinggi \\
\hline Nitrogen $(\mathrm{N})$ & $<0,10-0,20$ & $0,21-0,50$ & $0,51->0,75$ \\
\hline Phospor $(\mathrm{P})$ & $<8,0-15$ & $16-25$ & $26->35$ \\
\hline Kalium $(\mathrm{K})$ & $<0,10-0,20$ & $0,30-0,50$ & $0,60->1,00$ \\
\hline PH & Masam, $<4,5-5,5$ & Agak Masam $5,6-6,5$ & Netral $6,6-7,5$ \\
\hline
\end{tabular}

Sumber : Data Sekunder Hardjowigeno (1987).

\section{HASIL DAN PEMBAHASAN \\ Ciri Kimia Tanah Awal}

Hal yang pertama sekali dilakukan adalah pengambilan sampel tanah Ultisol. Tanah Ultisol merupakan tanah yang memilki kadar $\mathrm{pH}$ yang rendah berkisar 5,5 dan kandungan $\mathrm{N}, \mathrm{P}, \mathrm{K}$ yang juga dua tahap. Tahap I adalah pembuatan kascing dengan jalan memelihara cacing tanah selama 3 minggu (untuk priode I) . Sebagai media hidup cacing tanah digunakan sekam kayu, kotoran sapi, dan kotoran ayam yang sudah matang dengan perbandingan $3: 2: 1$, semua bahan diaduk rata, kemudian diambil sampelnya untuk pengukuran $\mathrm{pH}$ dan kadar air media, selanjutnya media tersebut dimasukkan kedalam plastik sebanyak 2 $\mathrm{kg}$ kering mutlak. Bibit cacing tanah dengan ukuran $5 \mathrm{~cm}$ disebar kedalam wadah pemeliharaan sebanyak $250 \mathrm{~g}$ per wadah. Kemudian wadah disimpan kedalam rak.

Pada percobaan pada tahap I ini sebagai perlakuan adalah jenis bahan makanan yang diberikan secara berbeda yang diberikan satu kali dalam tiga hari. Makanan yang diberikan adalah sebanyak 250 g kering mutlak. Pemberian makan yang dilakukan adalah limbah kangkung $300 \mathrm{~g}$ (KA 278\%) dan limbah bayam $400 \mathrm{~g}$ (KA 390\%) kemudian makanan tersebut diaduk rata dalam sebuah wadah. Perawatan dilakukan dengan mengadukaduk media agar sirkulasi udara baik, yang dilakukan pada waktu pemberian makanan. Pada tahap II dilakukan analisis unsur hara tanah di laboratorium USU Medan. Penelitian ini menggunakan metode deskriptif dengan mengacu pada indikator pada tabel dibawah ini. rendah, sehingga jika digunakan sebagai lahan pertanian dapat menyebabkan pertumbuhan tanaman tidak sempurna. Tanah ultisol biasanya memiliki kesuburan yang rendah untuk pertanian, karena ultisol memiliki kapasitas tukar kation yang rendah, dan ber-pH masam, 


\section{ge Ografi}

namun apabila dikelola dengan baik, dan iklim yang memungkinkan maka tanah ultisol juga dapat menjadi lahan pertanian yang dapat menghasilkan.

Ultisol merupakan tanah yang terbentuk di bawah iklim dengan, curah hujan besar dan biasanya terdapat di hutan. Karena di hutan banyak mengandung sisa-sisa bahan organik maka tanah ini biasanya bersifat masam. Tanah ultisol berwarna merah kekuningan. Kekhasannya ditandai oleh horizon putih yaitu horizon yang bahan organik dan besinya telah tercuci, jadi hanya tersisa silikanya saja (Brady dan Bucman, 1982).

Bila salah satu faktor lebih kuat pengaruhnya dari faktor lain sehingga faktor lain tersebut tertutupi dan masingmasing faktor mempunyai sifat yang jauh berbeda pengaruhnya dan sifat kerjanya, maka akan menghasilkan hubungan yang berbeda dalam mempengaruhi pertumbuhan suatu tanaman (Sutedjo dan Kartasapoetra, 2006). Tan (1994) juga mengatakan meskipun utisol memiliki sifat fisika dan kimia yang kurang baik, namun dengan pemupukan tanah dapat menjadi produktif.

Pengambilan sampel tanah Ultisol dilakukan di daerah Kuala Bekala, daerah ini merupakan salah satu tempat yang memiliki keadaan unsur tanah yang tidak baik, yakni tanah Ultisol.

Setelah itu dilakukan pengecekan analisis awal terhadap tanah Ultisol ini. Hasil analisis tanah awal beberapa sifat kimia tanah ultisol meliputi $\mathrm{pH}\left(\mathrm{H}_{2} \mathrm{O}\right), \mathrm{N}$ - total, P - avl Bray II, K- tukar yang disajikan pada tabel.

Dari tabel 3 terlihat bahwa tanah
Available at http://jurnal.unimed.ac.id/2012/index.php/geo e-ISSN: 2549-7057 | p-ISSN: 2085-8167

ini mempunyai sifat kimia yang kurang baik karena $\mathrm{N}, \mathrm{P}$ dan $\mathrm{K}$ yang rendah serta reaksi tanah yang masam.Ini karena Ultisol merupakan tanah yang mengalami pelapukan lanjut, suhu dan curah hujan yang tinggi, sehingga mengalami pencucian basa-basa yang sangat intensive pada lapisan atas tanah, maka tanah ini kurang baik bila dilihat dari sifat biologi, sifat fisika, dan sifat kimia tanah. Jika kondisi kimia tanah tersebut tidak diperbaiki, maka akan menyebabkan pertumbuhan tanaman terhambat terutama akibat kemasaman tanah dan kekurangan unsure N. Kriteria penentuan sifat kimia tanah ini disesuaikan dengan kriteria Hardjowigeno (1987).

Rendahnya bahan organik, N, P, K menunjukkan bahwa tanah pada percobaan ini membutuhkan bahan organik. Pemberian bahan organik seperti cacing diharapkan dapat meningkatkan Produktivitas Ultisol dimana Kascing mempunyai sifat-sifat kimia, fisika, dan biologi tanah yang baik, sehingga dapat meningkatkan serapan hara dan pertumbuhan tanaman. Hal ini dinamakan pengomposan dengan teknik vermikompos.

Teknik vermikompos atau kascing adalah kompos yang diperoleh dari hasil perombakan bahan-bahan organik yang dilakukan oleh cacing tanah. Kascing merupakan campuran kotoran cacing tanah dengan sisa media atau pakan dalam budidaya cacing tanah. Oleh karena itu, kascing merupakan pupuk organik yang ramah lingkungan dan memiliki keunggulan tersendiri dibandingkan dengan kompos lain (Mashur, 2001).

Tabel 3 . Hasil analisis beberapa sifat kimia Ultisol Kuala Berkala

\begin{tabular}{|l|l|l|l|}
\hline No & Sifat Tanah & Nilai & Kriteria \\
\hline 1. & $\mathrm{pH}\left(\mathrm{H}_{2} \mathrm{O}\right)$ & 5,02 & Masam \\
2. & N-total $(\%)$ & 0,15 & Rendah \\
3. & $\mathrm{K}(\mathrm{me} / 100 \mathrm{~g})$ & 0,25 & Rendah \\
4. & $\mathrm{P}(\mathrm{ppm})$ & 9,30 & Rendah \\
\hline
\end{tabular}

Sumber: Data Primer Laboratorium USU 2015

Setelah itu, dilakukan pengambilan sekam kayu, kotoran sapi 
dan kotoran ayam yang sudah matang dengan perbandingan $3: 2: 1$. Bahanbahan ini akan digunakan untuk proses inkubasi tanah ultisol yang telah didapat dari Kuala Berkala. Proses inkubasi merupakan proses pencampuran antara sekam kayu, kotoran sapi dan kotoran ayam beserta tanah ultisol. Hal ini dilakukan, untuk menjadikan kondisi kimia tanah mengalami perubahan yang baik, sehingga menjadi media yang baik untuk perkembangbiakan bibit cacing.

Pengadaan media ini dapat dengan diperoleh disekitar masyarakat. Sekam kayu dapat diperoleh ditempat pengolahan kayu atau sering disebut "panglong papan". Kotoran sapi dapat diperoleh dari rumah penduduk yang memelihara sapi atau ditempat peternakan sapi dalam skala besar. Sedangkan kotoran ayam dapat diperoleh dirumah penduduk atau peternakan ayam. Setelah itu dilakukan proses inkubasi dengan terlebih dahulu melakukan pencampuran tanah ultisol, sekam kayu, kotoran sapi dan kotoran ayam.

Setelah itu tanah diinkubasi selama 10 hari. Kemudian dianalisis kimia tanahnya dilaboratorium untuk melihat perubahan sifat kimia tanahnya. Hasilnya tertera didalam tabel 4 .

Tabel 4. Hasil analisis beberapa sifat kimia tanah inkubasi

Ultisol Kwala Bekala

\begin{tabular}{|c|l|c|c|}
\hline No & Sifat Tanah & Nilai awal & Nilai inkubasi \\
\hline 1. & $\mathrm{pH}\left(\mathrm{H}_{2} \mathrm{O}\right)$ & 5,02 & 6,01 \\
2. & N-total $(\%)$ & 0,15 & 0,27 \\
3. & $\mathrm{~K}(\mathrm{me} / 100 \mathrm{~g})$ & 0,25 & 0,61 \\
4. & $\mathrm{P}(\mathrm{ppm})$ & 9,30 & 9,51 \\
\hline
\end{tabular}

Sumber : Data Primer Laboratorium USU 2015

Terdapat perubahan sifat kimia tanah pada setiap aspek kimia tanah yang dinilai setelah dilakukan inkubasi pada tanah ultisol tersebut. Hal ini dikarenakan, kotoran ayam, kotoran sapi dan sekam kayu membantu perubahan kimia tanah tersebut. Selanjutnya pengadaan bibit cacing dapat dilakukan dengan pengambilan cacing disekitar rumah, dibawah pohon atau tempat yang lembab tempat biasa cacing hidup. Bibit cacing dapat juga diperoleh dengan membeli pada penjual makanan ternak atau dilabratorium pertanian. Setelah itu, bibit cacing dapat dimasukkan kedalam tanah inkubasi, diberi makan setiap harinya sebanyak bobot cacing yang dimasukkan dan siap dipanen selama tiga minggu.

\section{Pertumbuhan Berat Cacing Tanah}

Salah satu parameter yang dapat menjadi indikator terhadap pertumbuhan cacing tanah adalah pengamatan bobot cacing tanah. Hasil pengamatan terhadap bobot cacing tanah saat panen dengan metode gravimetric dapat dilihat tabel 5 berikut:

Tabel 5. Pertumbuhan Cacing Tanah

\begin{tabular}{|c|c|c|c|}
\hline No & Perlakuan & $\begin{array}{c}\text { Bobot Cacing Tanah } \\
\text { (gram) }\end{array}$ & $\begin{array}{c}\text { Perubahan Bobot } \\
\text { (gram) }\end{array}$ \\
\hline 1 & Kangkung & 250 & 450 \\
\hline 2 & Bayam & 250 & 650 \\
\hline
\end{tabular}

Sumber: Data Primer, 2015

Tabel diatas dapat dilihat bahwa

jenis makanan sangat berpengaruh 


\section{ge Ografi}

terhadap bobot cacing tanah. Jenis makanan kangkung menghasilkan cacing dengan bobot yang lebih tinggi baik dibandingkan jenis makanan bayam. Pertumbuhan cacing tanah yang diberi pakan kangkung, bobot cacing mengalami perubahan berat dua kali dari bibit cacing diawal. Akan tetapi, anak cacing hanya banyak ditemukan. Sebaliknya, dengan
Available at http://jurnal.unimed.ac.id/2012/index.php/geo e-ISSN: 2549-7057 | p-ISSN: 2085-8167

pemberian pakan bayam berat cacing mencapai 450 gram, namun anak cacing sedikit ditemukan. Hal ini, dapat dinyatakan bahwa jenis makanan sangat berpengaruh terhadap bobot cacing tanah. Seperti yang terlihat pada Tabel 6 yang menunjukkan kadar nutrient pada pakan kangkung dan bayam.

Tabel 6 Kandungan Nutrien Protein Dari Sumber Makanan Cacing Tanah

\begin{tabular}{|c|c|c|c|}
\hline \multirow{2}{*}{ No. } & \multirow{2}{*}{ Kandungan Nutrient } & \multicolumn{2}{|c|}{ Sumber Makanan } \\
\cline { 3 - 4 } & & Kangkung (gr) & Bayam (gr) \\
\hline 1 & Karbohidrat & $5,63 \mathrm{gr}$ & $6,5 \mathrm{gr}$ \\
\hline 2 & Energi & $28 \mathrm{kcal}$ & $36 \mathrm{kkal}$ \\
\hline 3 & Lemak & $0,4 \mathrm{gr}$ & $0,5 \mathrm{gr}$ \\
\hline 4 & Protein & $1,9 \mathrm{gr}$ & $3,5 \mathrm{gr}$ \\
\hline
\end{tabular}

Sumber: Data Sekunder, 2015

Dari tabel 6 diketahui bahwa makanan terutama kadar protein, karbohidrat dan lemak merupakan faktor yang mempengaruhi terhadap pertambahan bobot cacing tanah. Tingginya kadar nutrient tersebut dalam bayam menyebabkan lebih tingginya bobot cacing tanah yang dihasilkan.

\section{Kualitas Kascing}

Produksi kascing merupakan jumlah kascing yang dihasilkan selama pemeliharaan cacing tanah, sedangkan kualitas ditentukan oleh sifat fisik, kimia dan biologi dari kascing yang dihasilkan. Parameter yang menjadi indicator terhadap produksi dan kualitas kascing diantaranya adalah kandungan hara $\mathrm{N}, \mathrm{P}$, $\mathrm{K}, \mathrm{pH}$.

\section{Kandungan N Kascing}

Hasil analisis terhadap kandungan $\mathrm{N}$ total kascing dapat di lihat pada Tabel berikut ini:

Tabel 7 . Kandungan N Total Kascing

\begin{tabular}{|c|c|c|}
\hline No & Perlakuan & $\mathbf{N}$ \\
\hline 1 & Kangkung & $0,35(\%)$ \\
2 & Bayam & $0,47(\%)$ \\
\hline
\end{tabular}

Sumber: Analisis data primer, 2015

Dari tabel dapat dilihat bahwa jenis makanan dan lama pemeliharaan cacing tanah berpengaruh nyata terhadap kandungan $\mathrm{N}$ Total kascing. Jenis makanan bayam menghasilkan kascing dengan kandungan $\mathrm{N}$ Total yang lebih tinggi dari kangkung dan semakin lama pemeliharaan cacing tanah kandungan $\mathrm{N}$ Total juga semakin tinggi. Tingginya kadar protein dalam ampas tahu menyebabkan tingginya kandungan $\mathrm{N}$
Total dalam kascing. Protein adalah senyawa yang tersusun atas gugus asam amino yang merupakan sumber penting bagi N organik.

Tingginya kandungan $\mathrm{N}$ dalam kotoran cacing tanah juga disebabkan oleh proses metabolisme dalam tubuh cacing itu sendiri juga menghasilkan $\mathrm{N}$. Selanjutnya gejala-gejala tanaman kekurangan $\mathrm{N}$ diantaranya adalah tanaman kerdil, pertumbuhan akar 
terbatas serta daun-daun kuning dan gugur dan gejala tanaman kebanyakan $\mathrm{N}$ diantaranya adalah memperlambat kematangan tanaman ( terlalu banyak pertumbuhan vegetatif), batang-batang lemah mudah roboh dan mengurangi daya tahan tanaman terhadap penyakit (Hardjowigeno,1987).

Selanjutnya hasil penelitian Elfayetti (2003) mengatakan dengan penambahan pemberian kascing 20 ton/ha akan meningkatkan kandungan $\mathrm{N}$-total pada tanah dan dengan pemberian kascing pada tanaman jagung akan meningkatkat kadar hara $\mathrm{N}$ pada tanaman ini juga sejalan dengan penelitian Damayanti (1994) melaporkan makin tinggi taraf kascing maka makin meningkat serapan $\mathrm{N}$ pada tanaman Kedelai.

\section{Kandungan P Kascing}

Tabel 8 Hasil Analisis P Tersedia Kascing

\begin{tabular}{|c|c|l|}
\hline No & Perlakuan & \multicolumn{1}{c|}{ P } \\
\hline 1. & Kangkung & $6,48(\mathrm{ppm})$ \\
\hline 2. & Bayam & $46,94(\mathrm{ppm})$ \\
\hline
\end{tabular}

Sumber: Data Primer Laboratorium USU, 2015

Hasil analisis $\mathrm{P}$ tersedia kascing dapat disimpulkan bahwa jenis makanan dan lama pemeliharaan cacing tanah berpengaruh terhadap kandungan $\mathrm{P}$ tersedia kascing. Kandungan $\mathrm{P}$ kascing tertinggi diperoleh pada jenis makanan bayam. Hal ini dapat dihubungkan dengan hasil analisis terhadap $\mathrm{P}$ yang terkandung dalam makanan cacing tanah tersebut, dimana kandungan $\mathrm{P}$ dalam bayam lebih tinggi dari jenis makanan kangkung. Suin (1988) menyatakan kandungan hara kascing sangat ditentukan oleh jenis bahan organik yang dimakannya. Disamping kandungan $\mathrm{P}$ total dalam bahan makanan, maka keberadaan sumber $\mathrm{C}$ dan $\mathrm{N}$ dalam jumlah besar, berbagai mikroba mempunyai potensi untuk membongkar asam nukleat dan membebaskan $P$.

Hasil penelitian Elfayetti (2003) melaporkan dengan pemberian kascing 20 ton/ha. pada tanaman jagung akan meningkatkan serapan $\mathrm{P}$ pada tanaman. Unsur hara makro tanaman salah satunya adalah unsur P. Unsur hara P memiliki peranan yang sangat penting didalam keberlangsungan pertumbuhan dan perkembangan tanaman, yaitu mempercepat pertumbuhan akar, mempercepat pendewasaan tanaman, mempercepat pembentukan buah dan biji serta meningkatkan produksi (Isnaini, 2006).

Besarnya $P$ tanah akibat pemberian kascing disebabkan karena P-total kascing tinggi dan juga $\mathrm{P}$ yang dilepas dari komplek Al-P akibat adanya asam-asam organik yang mengkelat $\mathrm{Al}$.

\section{Kandungan K kascing}

Tabel 9. Hasil analisis terhadap K kascing

\begin{tabular}{|c|c|c|}
\hline No & Perlakuan & K \\
\hline 1 & Kangkung & $1,82(\mathrm{me} / 100 \mathrm{gr})$ \\
2 & Bayam & $0,63(\mathrm{me} / 100 \mathrm{gr})$ \\
\hline
\end{tabular}

Sumber: Data Primer laboratorium USU, 2015

Dari tabel diatas nampak bahwa jenis makanan mempengaruhi kandungan $\mathrm{K}$ tukar kascing begitu juga dengan kandungan nutrient dari jenis makanan itu sendiri. Dengan adanya asam-asam organik dalam kascing baik dari hasil 


\section{gệgrafi}

pelapukan bahan organik maupun yang dikeluarkan mikrobia yang dapat meningkatkan K-dd.Analisa laboratorim $\mathrm{K}$ kascing dengan makanan kangkung lebih tinggi dari pada cacing yang diberi makan bayam.

Hasil penelitian Elfayetti (2003) melaporkan dengan pemberian kascing pada tanaman jagung akan meningkatkan
Available at http://jurnal.unimed.ac.id/2012/index.php/geo e-ISSN: 2549-7057 | p-ISSN: 2085-8167

kadar hara $\mathrm{K}$, hal ini disebabkan kandungan $\mathrm{K}$ dalam Kascing sehingga meningkatkan $\mathrm{K}$ dalam tanah.

\section{Kandungan $\mathrm{pH}$ kascing}

Hasil analis dari kandungan kascing dari ampas tahu dan kol menunjukan keadaan $\mathrm{pH}$ sebagai berikut:

Tabel 10. Hasil analisis pH kascing.

\begin{tabular}{|c|c|c|c|}
\hline No & Perlakuan & $\mathbf{p H}$ & Kriteria \\
\hline 1. & Kangkung & 6,05 & Netral \\
2. & Bayam & 7,41 & Netral \\
\hline
\end{tabular}

Sumber: Data Primer, 2015

Dari tabel diatas dapat disimpulkan bahwa $\mathrm{pH}$ kascing meningkat (netral) dengan adanya perlakuan makan cacing kangkung dan bayam. Kascing mempunyai kelebihan dari pupuk organik lainnya, karena selain mempunyai hampir semua unsur-unsur yang dibutuhkan oleh tanaman, kascing juga mengandung unsur makro yang lebih tinggi, dan kascing juga mampu menetralkan $\mathrm{pH}$ tanah (Liptan, 2001). Selain mengandung hampir semua unsur hara yang dibutuhkan oleh tanaman dalam jumlah yang tersedia, kascing juga mengandung hormon tumbuh tanaman. Hormon tersebut akan memacu pertumbuhan tanaman, akar tanaman di dalam tanah, memacu pertunasan rantingranting baru pada batang dan cabang pohon, serta memacu pertumbuhan daun (Yuwono, 2006). Hormon tersebut akan memacu pertumbuhan tanaman, akar tanaman di dalam tanah, memacu pertunasan ranting-ranting baru pada batang dan cabang pohon, serta memacu pertumbuhan daun.

\section{KESIMPULAN DAN SARAN}

Berdasarkan penelitian yang telah dilakukan maka dapat ditarik beberapa kesimpulan sebagai berikut:

1. Jenis makanan berpengaruh terhadap pertumbuhan cacing tanah dan kualitas kascing yang dihasilkan.
2. Terdapat perbedaaan pada bobot cacing tanah yang dihasilkan dengan adanya perbedaan jenis makanan. Jenis makanan bayam memberikan tingkat pertumbuhan cacing tanah terbaik dengan terjadinya pertambahan bobot sebesar 650 gram yang awalnya hanya 250 gram.

3. Dari beberapa parameter sifat kimia dan biologi kascing, maka jenis makanan bayam memberikan nilai $\mathrm{N}$ tertinggi yaitu 0,52 dan pada pakan kangkung terdapatnilai $\mathrm{p}$ tertinggi yaitu 0,35 .

Dari hasil penelitian ini disarankan melakukan variasi dalam pemberian makanan pada cacing tanah, sehingga lebih menguntungkan baik untuk pertumbuhan cacing tanah maupun produksi dan kualitas kascing yang dihasilkan. Untuk tanaman yang membutuhkan nilai $\mathrm{N}$ dan $\mathrm{P}$ tinggi dapat menggunakan pupuk vermikompos yang diberi pakan bayam. Sedangkan bagi tumbuhan yang membutuhkan kadar $\mathrm{K}$ tinggi dapat menggunakan pupuk vermikompos yang diberi pakan kangkung

\section{DAFTAR PUSTAKA}

Brady, N dan Buckman H. 1982. Ilmu Tanah. Bhratara Karya Aksara. 
Jakarta.

Damayanti M, 1994. Usaha perbaikan beberapa sifata kimia Ultisol, serapan hara dan hasil kedelai dengan pemberian kapur dan kascing Tesis magister UNPAD Bandung.

Hardjowigono, 1996. Genesis, dan Kualifikasi tanah, Institut Pertanian Bogor

Isnaini, M., 2006. Pertanian Organik Untuk Keuntungan Ekonomi dan Kelestarian Bumi. Kreasi Wacana. Jakarta.

Liptan. 2001. Pertanian Organik. Balai Pengkajian Teknologi Pertanian (BPTP).Pekan Baru.

Sudirja, R, 1999, Budidaya cacing tanah, Assosiasi kultur vermi Indonesia, Jatinangor.

Suin, N.M, 1988, Populasi hewan tanah disekitar pabrik semen serta kemungkinannya bagi pemantauan kualitas tanah, Desertasi Doktot ITB Bandung.

Sutedjo, M. M. dan Kartasapotra . 2006.

Pupuk dan Cara Pemupukan. Edisi ke-5.Rineka Cipta, Jakarta.

Yuwono, D. 2006. Kompos, Seri Agritekno. Penebar Swadaya. Jakarta. 